\title{
Penanganan fluorosis pada gigi sulung dengan menggunakan teknik mikroabrasi
}

\author{
Muh. Harun Achmad \\ Bagian Ilmu Kedokteran Gigi Anak \\ Fakultas Kedokteran Gigi Universitas Hasanuddin
}

\begin{abstract}
Fluorosis is a pathological endemic effect of ion intake of flour which is more than 1 ppm. Enamel fluorosis is tooth enamel demineralization due to excessive flour intake during tooth calcification period. Fluorosis is disparity of tooth which is initially marked with a white line across the enamel surface, and at severe level can change tooth form. Dental fluorosis is hypoplasia or hypomaturation of tooth enamel or dentine because of chronic usage of excessive fluor at period and development of dentition. Dental fluorosis is qualitative defect of enamel, resulted from the increase of fluor concentration at cell microenvironment of ameloblast during development and tooth formation. Quantitative defect of enamel can occur on severe type of dental fluorosis. Microabrasion, consist of air abrasion and enamel microabrasion, is a method of reducing tooth structure which is the best alternative rather than drilling method. The mechanism of air abrasion technique is blast pressure of abrasive particles to remove tooth caries. The principle of kinetic energy is the abrasive particles with high pressure and speed, hit the tooth, remove tooth caries, and reduce tooth structure.
\end{abstract}

Key word: fluorosis, microabrasion technique

\begin{abstract}
ABSTRAK
Fluorosis merupakan efek endemik patologis karena asupan ion fluor yang lebih dari 1 ppm. Fluorosis email merupakan demineralisasi email gigi akibat asupan fluor yang berlebih pada masa kalsifikasi gigi. Fluorosis gigi adalah kelainan gigi yang pada awalnya ditandai dengan suatu garis putih yang berjalan menyilang pada permukaan email, dan pada tingkat yang berat dapat merubah bentuk gigi. Fluorosis gigi adalah hipoplasia atau hipomaturasi email gigi atau dentin karena penggunaan kronis fluor yang
\end{abstract}


berlebih pada masa perkembangan dan pertumbuhan gigi tetap. Fluorosis gigi adalah defek kualitatif email dihasilkan oleh peningkatan konsentrasi fluor pada microenvironment sel ameloblas selama masa pembentukan dan perkembangan gigi. Pada fluorosis gigi jenis berat dapat terjadi defek kuantitatif email. Mikroabrasi yang terdiri dari abrasi udara dan mikroabrasi email, adalah metode pengurangan struktur gigi yang merupakan alternatif terbaik setelah penggunaan metode bor biasa. Teknik abrasi udara bekerja dengan mekanisme tekanan semburan partikel-partikel abrasif yang dapat menghilangkan karies pada gigi. Prinsip energi kinetik yang terjadi adalah partikelpartikel abrasif dengan tekanan dan kecepatan tinggi akan mengenai gigi sehingga akan menghilangkan karies pada gigi dan mengurangi struktur gigi.

Kata kunci: fluorosis, teknik mikroabrasi

Koresponden: Muh. Harun Achmad, Bagian Ilmu Kedokteran Gigi Anak, Fakultas Kedokteran Gigi Universitas Hasanuddin, Jl. Kandea No.5 Makassar, Indonesia.

\section{PENDAHULUAN}

Fluorosis adalah hipomineralisasi email yang disebabkan retensi protein amelogenin oleh fluoride sehingga email tidak mengalami maturasi sehingga menyebabkan permukaan luar dan subsurface berporus. Fluorosis gigi adalah defek kualitatif email yang dihasilkan oleh peningkatan konsentrasi fluor pada microenvironment sel ameloblast selama masa pembentukan dan perkembangan gigi. Pada fluorosis gigi jenis berat dapat terjadi defek kuantitatif email.1,2

Secara umum, fluorosis merupakan suatu kelainan, sejenis hipoplasia email yang disebabkan oleh asupan fluor yang berlebih, baik secara sistemik maupun lokal. Hal tersebut menyebabkan perubahan warna email yang bervariasi, mulai bintik putih buram hingga berwarna coklat.2

Tanda awal gigi terpapar fluor berlebih adalah email yang berbintik-bintik dan disebut sebagai mottled enamel. Istilah mottled enamel digunakan untuk menggambarkan beberapa gejala dan akibat dari fluorosis gigi atau fluorosis endemik.1,2

Kejadian fluorosis tidak hanya pada gigi sulung tetapi juga pada gigi permanen. Menurut beberapa peneliti, fluorosis gigi sulung dianggap berhubungan dengan kejadian fluorosis pada gigi permanen, sehingga perlu mengamati kemungkinan 
meningkatnya resiko fluorosis pada gigi permanen. Beberapa kondisi umum fluorosis gigi sulung, misalnya fluorosis gigi sulung jarang terjadi dan kurang parah jika dibandingkan fluorosis gigi permanen serta fluorosis biasanya sulit dideteksi dengan menggunakan sumber cahaya yang tidak adekuat, prevalensi dan keparahan fluorosis gigi sulung berhubungan dengan konsentrasi fluor dalam air, dan pada daerah yang tinggi konsentrasi fluornya pada air dan konsumsi airnya tinggi, fluorosis gigi sulung dapat terjadi pada semua gigi, Meskipun demikian, jika dibandingkan dengan gigi sulung lainnya, penyakit ini lebih sering menyerang molar sulung. 1-3

Terdapat beberapa tingkatan fluorosis, yaitu fluorosis ringan, fluorosis sedang, dan fluorosis berat. Pada fluorosis ringan, email masih bisa tahan terhadap serangan asam. Sedangkan kelainan pada fluorosis sedang kadang mengganggu kadang juga tidak. Pada fluorosis berat, keadaan ini dilihat secara estetik akan sangat mengganggu penderita.1,2

Sebelum berkembangnya teknik mikroabrasi pada saat ini, penanganan fluorosis awalnya hanya dilakukan dengan cara metode bor.

Penanganan fluorosis pada umumnya didasarkan pada pertimbangan nilai estetik, pengembalian fungsi serta pertimbangan ekonomi pada pasien penderita fluorosis. Penanganan restorasi pada fluorosis dapat menggunakan bahan glass ionomer, maupun resin komposit tergantung pada kondisi fluorosis itu sendiri.1,2

Adapun keunggulan teknik mikroabrasi dibanding dengan metode bor adalah teknik mikroabrasi tidak menimbulkan rasa sakit, nyeri dan linu, tidak menghasilkan getaran, gesekan dan panas seperti pada metode bor, menghilangkan jaringan email sedikit mungkin dan merupakan prosedur yang selektif karena hanya menghilangkan struktur gigi yang rusak, waktu kerja yang lebih cepat, dan tidak membahayakan jaringan lunak sekitar gigi.4-6

Penulisan makalah ini dimaksudkan untuk membahas penanganan awal fluorosis, sebelum dilakukannya aplikasi bahan restorasi, dengan menggunakan teknik mikroabrasi.

\section{TINJAUAN PUSTAKA}

\section{Teknik mikroabrasi}

Dikenal dua jenis teknik mikroabrasi, yaitu abrasi udara (air abrasion) dan mikroabrasi email (enamel microabrasion). Mikroabrasi sendiri adalah metode pengurangan struktur gigi yang 
merupakan alternatif dibandingkan penggunaan metode bor biasa. 6

\begin{abstract}
Abrasi udara
Abrasi udara yang dikenal juga sebagai teknik kinetic cavity preparation, merupakan metode alternatif terbaik dalam pembuatan kavitas kecil selain metode bor biasa.6 Abrasi udara pertama kali dikemukakan oleh Dr. Robert Black pada tahun 1943. Namun metode abrasi udara ini baru terkenal pada tahun 1940-an hingga pertengahan tahun 1950-an ketika bor high speed air turbine dikembangkan. Abrasi udara diperkenalkan kembali kepada ilmu kedokteran gigi pada tahun 1990-an oleh Dr. Kutsch yang telah mengembangkan dan membuat hak paten atas teknik Abrasi udara.7
\end{abstract}

\section{Mekanisme kerja abrasi udara}

Teknik abrasi udara bekerja dengan mekanisme tekanan semburan partikelpartikel abrasif yang dapat menanggulangi karies pada gigi. Prinsip energi kinetik yang terjadi adalah partikel-partikel abrasif dengan tekanan dan kecepatan tinggi akan mengenai gigi sehingga akan mengurangi karies pada struktur gigi.6

Abrasi udara dilakukan dengan menggunakan mesin (gambar 1) dan alat- alat khusus. Mesin yang dapat digunakan, salah satunya adalah Kreativ's Mach 5 yang mempunyai ukuran diameter nozzle 0,0110,036 inchi dengan sudut $45^{\circ}$ dan $90^{\circ}$. Keberhasilan metode abrasi udara dipengaruhi oleh ukuran, jenis dan kekerasan partikel-partikel abrasif, besar tekanan udara, besarnya tekanan aliran air, diameter nozzle, sudut pengerjaan, dan substansi permukaan gigi.3,6

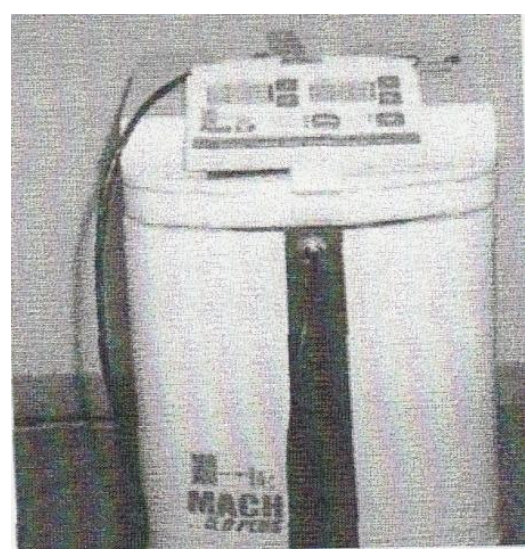

Gambar 1. Mesin untuk abrasi udara (Sumber: Micro abrasion dentistry technology. [online] 2005 [cited 2005]. Available from URL http://www.kutschandrenyer. com

Indikasi dan kontraindikasi abrasi udara. Teknik abrasi udara terutama digunakan untuk merawat dan membuat kavitas-kavitas kecil yang akan diisi oleh bahan restorasi glass ionomer atau komposit. Teknik abrasi udara hanya dapat dilakukan 
pada kavitas yang menggunakan bahan tambalan bukan logam karena preparasi yang dibuat, tidak bersudut dan lebih membulat, tidak akan kuat menahan bahan logam yang memerlukan dinding kavitas yang kokoh.7,8

Secara umum, abrasi udara dapat digunakan pada semua pasien, kecuali pasien dengan penyakit saluran pernafasan, seperti penyakit paru kronis dan alergi akut terhadap debu. Teknik ini merupakan alternatif terbaik pada pasien anak yang takut akan jarum suntik, suara bor dan getaran dengan metode bor biasa. Teknik abrasi udara tidak dapat digunakan sebagai alternatif untuk semua restorasi gigi, terutama untuk restorasi yang membutuhkan kavitas besar seperti restorasi cekat dan restorasi saluran akar.9

Teknik abrasi udara dapat digunakan untuk melakukan berbagai macam perawatan dan restorasi gigi, misalnya sealant. Abrasi udara dapat digunakan untuk membersihkan grooves, baik pada
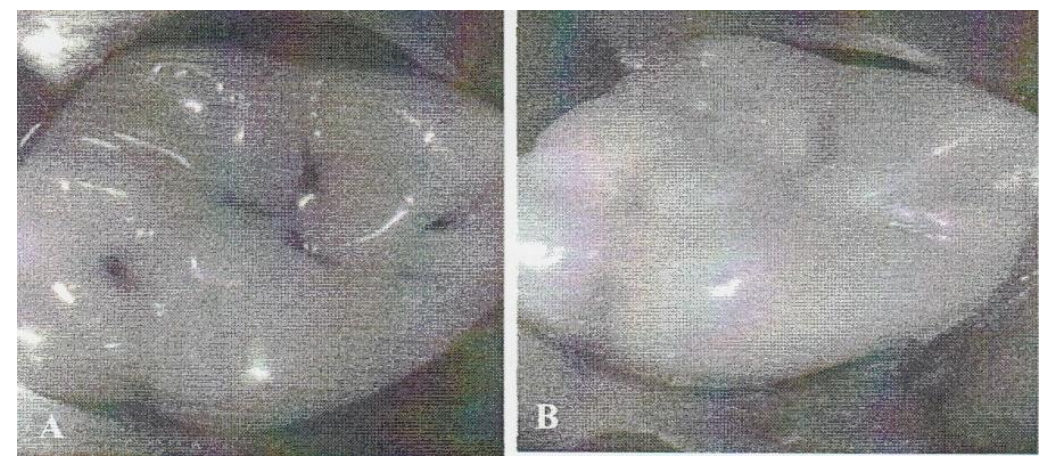

permukaan oklusal maupun labial gigi yang berupa retak pada gigi, yang akan diisi oleh bahan fissure sealant (gambar 2). Selain itu abrasi udara dapat membuat kavitas kelas satu yang kecil dan membersihkan fisur, selain kelas kelas dua dan kelas tiga. Pada kedokteran gigi kosmetik, abrasi udara digunakan untuk untuk memperbaiki kembali permukaan dan warna restorasi dari komposit, baik pada gigi anterior maupun gigi posterior. Selain itu teknik abrasi udara dapat digunakan pada perawatan akibat pewarnaan ekstrinsik dan intrinsik pada fluorosis. Pada karies kelas lima, sangat cocok ditangani dengan teknik abrasi udara. Anestesi akan diperlukan bila lesinya sangat dalam karena dapat menimbulkan reaksi sensitivitas yang berlebih pada saat pelaksanaan teknik ini. Selain itu teknik abrasi udara dapat dilakukan untuk memperbaiki defek lubang pada mahkota, perbaikan tonjol gigi dan membuat ikatan antara komposit dengan amalgam. 7,8 
Gambar 2. A. Gigi sebelum perawatan dengan teknik abrasi udara, B. Gigi setelah perawatan dengan teknik abrasi udara (Sumber : Air abrasion, microabrasion. [online] 2005 [cited 2005]. Available from URL http://www.pubmed.com

Keuntungan teknik abrasi udara

Beberapa keuntungan dari teknik abrasi udara, yaitu tidak menimbulkan rasa sakit, nyeri dan linu sehingga tidak memerlukan anestesi injeksi, tidak menghasilkan getaran, gesekan dan panas seperti pada metode bor biasa sehingga proses restorasi dapat berjalan dengan nyaman, menghilangkan jaringan email sedikit mungkin karena merupakan prosedur yang selektif hanya menghilangkan struktur gigi yang rusak, dapat mengurangi kemungkinan fraktur mikroskopik yang dapat terjadi bila menggunakan metode bor biasa, waktu kerja lebih cepat, dan tidak membahayakan jaringan lunak sekitar gigi.7,8

\section{Mikroabrasi email}

Teknik mikroabrasi email merupakan suatu cara untuk menghilangkan struktur email gigi dengan menggunakan bahan kimia yang dapat melarutkan permukaan email gigi. Mikroabrasi email tidak termasuk dalam teknik bleaching tetapi merupakan proses erosi selektif yang dapat menghilangkan pewarnaan pada email.
Teknik erosi email pertama kali diperkenalkan dengan menggunakan bahan kimia yang mengandung asam hidroklorit 18\% untuk menghilangkan pewarnaan fluorosis. Teknik ini terbukti ampuh hingga pada tahun 1939 Younger menunjukkan bahwa penggunaan asam hidroklorit dapat menyebabkan dekalsifikasi email dan meningkatkan kemungkinan kejadian karies sehingga pemakaian asam hidroklorit mulai berkurang. 10

Penggunaan hidrogen peroksida mulai terkenal sejak 1939 hingga tahun 1966 ketika Mclnnes memperkenalkan teknik erosi yang menggunakan campuran lima bagian dari asam hidroklorit 30\% dengan lima bagian dari hidrogen peroksida 30\% dan satu bagian etil eter untuk menghilangkan fluorosis. Larutan ini diaplikasikan pada gigi yang mengalami fluorosis selama 15-30 menit dan dinetralkan dengan sodium bikarbonat lalu dipoles. Meskipun teknik ini tidak menimbulkan rasa nyeri setelah perawatan, tetapi pasien melaporkan perasaan tidak nyaman ketika larutan tersebut diaplikasikan selama perawatan berlangsung. 10 
Teknik tersebut di atas kemudian dimodifikasi oleh Bailey dan Christen pada tahun 1970 dan efek dari penghilangan warna tersebut diperbesar dengan digunakannya cuttle discs untuk mengaplikasikan larutan tersebut. Pada tahun 1983 Murrin dan Barkmeier menggunakan kombinasi teknik bleaching untuk menghilangkan pewarnaan fluorosis. 10

$$
\text { Pada tahun } 1984 \text { McCloskey }
$$
mengembangkan teknik Kane dengan mengaplikasikan asam hidroklorit $18 \%$ dan pumis untuk memperbaiki efek abrasif terhadap email. Croll dan Cavanaugh mengembangkan teknik mikroabrasi email dengan mencampur $18 \%$ asam hidroklorit dan pumis menjadi suatu pasta yang dapat diaplikasikan pada gigi dengan menggunakan tongue blade yang telah dimodifikasi. Pada saat ini, Croll telah memodifikasi teknik mikroabrasi email dengan mengurangi konsentrasi asam hidroklorit menjadi $11 \%$ dan meningkatkan daya abrasif dengan memakai partikel silikon karbid dalam bentuk pasta yang mudah larut dalam air sebagai ganti penggunaan pumis.11

\section{Indikasi dan kontraindikasi mikroabrasi email}

Teknik mikroabrasi email khusus untuk perawatan semua jenis pewarnaan superfisial gigi vital yang terlokalisasi, baik ekstrinsik maupun intrinsik, terutama pewarnaan fluorosis ringan hingga sedang. Karena akan menghilangkan struktur gigi, teknik mikroabrasi email hanya diindikasikan untuk pewarnaan superfisial yang berada tidak lebih $0,3 \mathrm{~mm}$ dari permukaan email terluar. Teknik mikroabrasi email dapat menghilangkan pewarnaan putih opak pada email, defek pewarnaan multi-warna, pewarnaan spot coklat, oranye dan kuning tanpa melihat penyebab dari pewarnaan tersebut. Teknik mikroabrasi email juga dapat digunakan untuk perawatan dekalsifikasi email pasca perawatan ortodontik pada pasien dengan kebersihan mulut yang buruk.9,11

Penggunaan teknik mikroabrasi email harus selektif mungkin, terutama apabila terdapat restorasi pada gigi yang akan dirawat. Gigi dengan restorasi glas ionomer merupakan kontraindikasi teknik mikroabrasi email, karena dapat memperparah kekasaran permukaan dentin dan restorasi tersebut. Teknik mikroabrasi email dapat digunakan untuk memoles restorasi amalgam tetapi tidak untuk 
restorasi dengan porselen karena porselen resisten terhadap efek mikroabrasi.4,9

Teknik mikroabrasi email digunakan untuk mengatasi adanya pewarnaan gigi akibat fluorosis sebagai terapi awal yang diikuti oleh bleaching pada kasus pewarnaan yang berat (gambar 3). Secara umum pewarnaan sangat sulit untuk ditentukan letak dan kedalamannya pada permukaan sehingga mikroabrasi email dapat dilakukan sebagai perawatan awal. Perawatan lanjut dengan menggunakan metode pelapisan veneering) akan diperlukan apabila ternyata lesi tersebut terletak lebih dalam daripada perkiraan semula. 5

Keberhasilan teknik mikroabrasi email tidak dipengaruhi oleh etiologi pewarnaan. Pada fluorosis gigi, keberhasilan perawatan mikroabrasi email dapat diukur dengan indeks TF.1
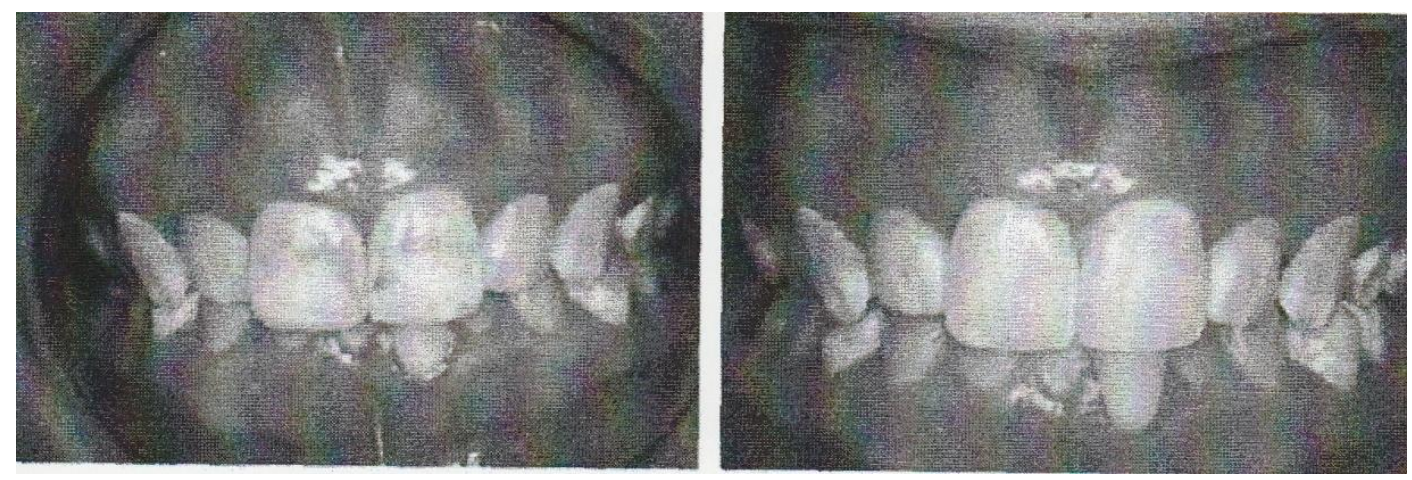

Gambar 3. A. Gigi 11 dan 12 yang mengalami fluorosis dental jenis sedang sebelum perawatan, B. setelah perawatan dengan teknik mikroabrasi email (Sumber : Air abrasion, microabrasion. [online] 2005 [cited 2005]. Available from URL http://www.pubmed.com

\section{Teknik mikroabrasi sebagai salah satu perawatan fluorosis gigi7,12,13}

Teknik mikroabrasi terutama ditujukan untuk perawatan fluorosis gigi dengan pewarnaan superfisial seperti bercak putih pada gigi. Fluorosis gigi jenis ringan hingga sedang, dengan skor TF antara 0-6 atau skor TSIF antara $0-5$ dan tidak mengalami kehilangan permukaan email dalam taraf besar, adalah indikasi utama untuk perawatan dengan teknik mikroabrasi. Teknik mikroabrasi merupakan kontraindikasi bagi pewarnaan yang terletak lebih dalam dari 0,2-0,3 $\mathrm{mm}$. Secara umum, pigmentasi pada fluorosis terbatas hanya pada sepertiga luar lapisan email. 
Teknik abrasi udara7,8,13

Teknik abrasif gigi dengan menggunakan prinsip energi kinetik atau kimia, sering kali digunakan sebagai perawatan awal pada bleaching untuk menghilangkan pewarnaan yang terlalu dalam atau untuk menghilangkan pewarnaan berupa spot putih atau coklat pada gigi. Teknik abrasi udara dapat dipertimbangkan sebagai bentuk kontrol perawatan pewarnaan pada gigi. Teknik abrasi udara merupakan metode konservatif yang dapat menghilangkan pewarnaan berupa spot putih atau coklat dan stain superfisial, terutama karena fluorosis gigi. Prosedur perawatan dengan teknik abrasi udara bertujuan menghilangkan pewarnaan dengan cara melakukan abrasi pada gigi dan menciptakan kavitas kecil yang kemudian dapat diisi dengan resin.

\section{Prosedur teknik mikroabrasi email4,9,13}

Teknik mikroabrasi email menggunakan bahan kimia dan partikel abrasif untuk menghilangkan pewarnaan gigi, terutama pewarnaan fluorosis gigi. Teknik mikroabrasi email, seperti juga pada teknik abrasi udara, dapat digunakan sebagai rangkaian perawatan pewarnaan fluorosis gigi pada kasus berat atau perawatan tersendiri pada kasus ringan.
Prosedur perawatan fluorosis gigi dengan teknik mikroabrasi email ditempuh dalam beberapa langkah. Pertama, dilakukan pengambilan foto keadaan gigi-geligi sebelum perawatan sebagai dokumentasi dan perbandingan sebelum perawatan dengan sesudah perawatan. Selanjutnya dilakukan pemeriksaan ketebalan permukaan labiolingual/labiopalatal, dapat dilakukan secara langsung dengan melihat dari insisal menggunakan kaca mulut atau dengan foto radiografik. Gigi dengan ketebalan labiolingual/labiopalatal yang normal dapat menerima perawatan yang lebih agresif. Pada proses selanjutnya, harus dijalankan tindakan pengamanan yang dilakukan secara cermat sehingga tidak terjadi pemaparan bahan asam hidroklorit yang tidak diinginkan. Pengamanan dapat dilakukan dengan penggunaan kacamata untuk pasien dan operator, rubber dam bagi pasien dan sarung tangan bagi operator. Air mengalir harus tersedia agar sisa asam mudah membersihkan. Pasta bahan mikroabrasi email harus diaplikasikan menggunakan contra-angle berkecepatan rendah (gambar 4) dengan rasio perputaran 10:1 atau dapat diaplikasikan dengan menggunakan instrumen tangan untuk mencegah terjadi cipratan. 
Aplikasi dengan instrumen putar dilakukan dengan menempatkan sejumlah kecil pasta pada gigi yang hendak dirawat selama 20-30 detik. Kemudian pasta dibersihkan dari gigi serta ketebalan labial lingual/palatal email diperiksa kembali menggunakan kaca mulut (gambar 5). Aplikasi dengan instrumen tangan terutama untuk lesi pewarnaan kecil, dapat diperoleh dengan menggunakan hand applicator, seperti rubber cup, tongue blade atau instrumen plastik. Bercak pewarnaan yang kecil dapat dihilangkan dengan baik menggunakan instrumen tangan selama 2030 detik. Aplikasi pasta dapat diulang beberapa kali hingga pewarnaan hilang. Apabila permukaan email sudah terlihat cekung dan pewarnaan belum hilang, maka diperlukan perawatan alternatif lain.
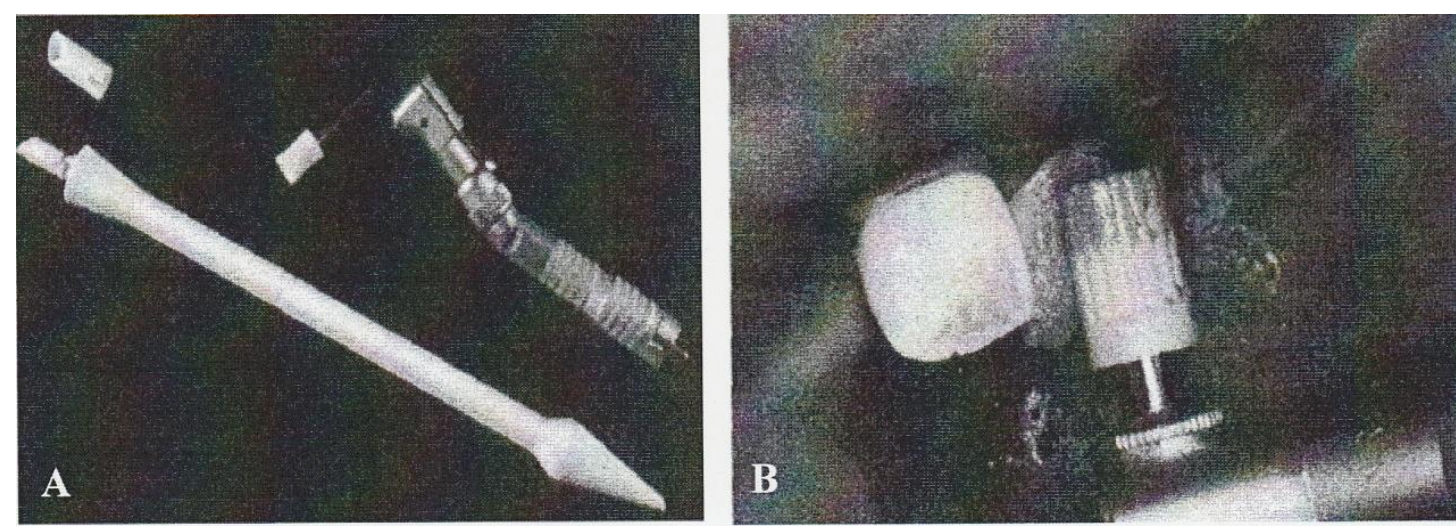

Gambar 4. A. Instrumen putar dan instrumen tangan untuk aplikasi bahan pada teknik mikroabrasi Email, B. Aplikasi pasta dengan instrumen putar (Sumber : Micro abrasion dentistry teknology [online] 2005 [cited 2005]. Available from URL http://www.kutschandrenyer.com
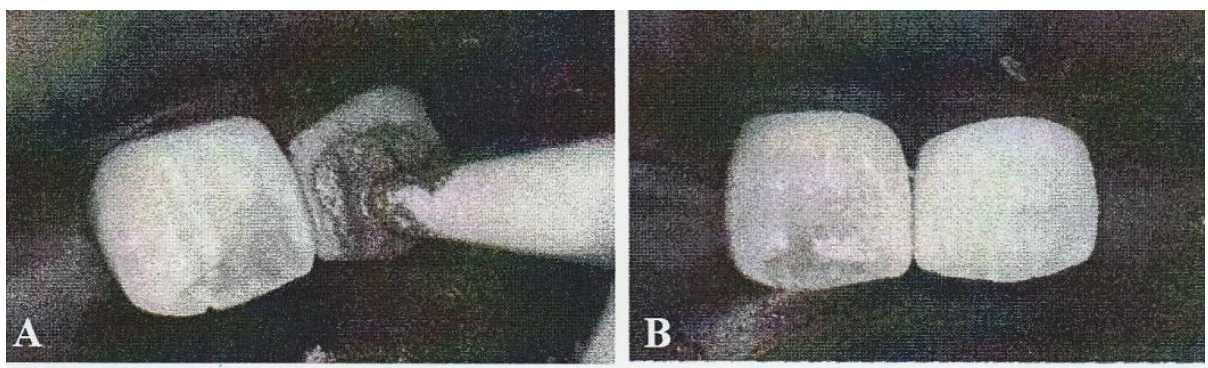

Gambar 5. A. Aplikasi pasta dengan instrumen tangan pada gigi 21 setelah lesi

Menjadi lebih kecil, B. Lesi pewarnaan pada gigi 21 telah hilang (Sumber : Micro abrasion dentistry teknology [online] 2005 [cited 2005]. Available from URL http://www.kutschandrenyer.com 

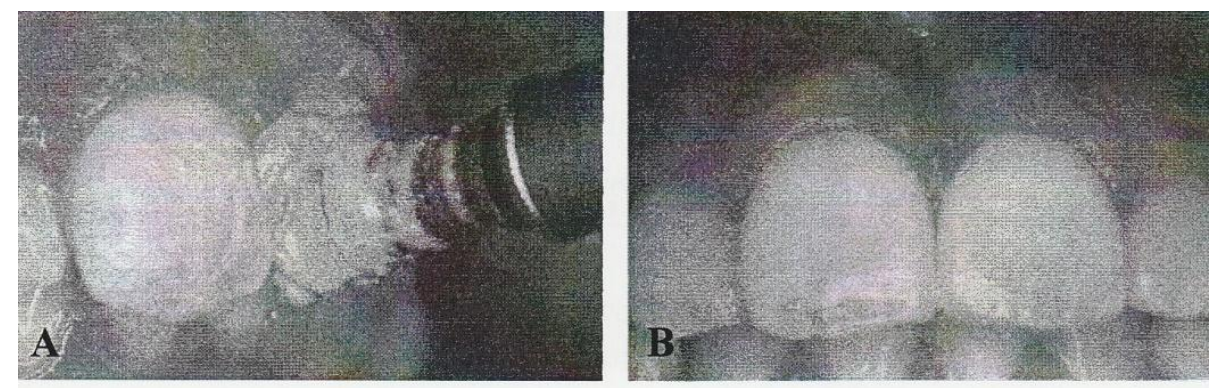

Gambar 6. A. Pemolesan menggunakan pasta profilaksis, B. Hasil akhir setelah Perawatan (Sumber : Micro abrasion dentistry teknology [online] 2005 [cited 2005]. Available from URL http://www.kutschandrenyer.com

Selanjutnya permukaan
dibasahi terlebih $\begin{array}{r}\text { dahulu } \\ \text { ketika }\end{array}$
mengevaluasi hasil perawatan karena
permukaan email yang kering dapat
mempengaruhi pewarnaan. Setelah aplikasi
pasta selesai, dilakukan aplikasi topikal
fluor. Aplikasi gel yang mengandung
sodium fluoride selama 4 menit merupakan
tindakan penetralan terhadap sisa asam
pada gigi. Hasilnya tampak pada gambar 6.
Pasien harus kembali $2-3$ minggu setelah
perawatan pertama untuk kontrol dan
dilakukan perawatan lanjutan bila gigi
mengalami rehidrasi. Tes sensitivitas gigi
dapat dilakukan pada kontrol satu bulan
setelah perawatan awal. Foto keadaan gigi-
geligi pasca perawatan dapat diambil pada
saat kontrol.

\section{SIMPULAN}

Fluorosis gigi terjadi akibat asupan fluor berlebih semasa pertumbuhan dan perkembangan gigi-geligi. Asupan fluor dapat terjadi secara sistemik, terutama berasal dari air minum, atau lokal. Teknik mikroabrasi, yang terdiri dari abrasi udara dan mikroabrasi email, dapat merupakan alternatif terbaik setelah penggunaan metode bor biasa dalam melakukan perawatan gigi baik restorasi gigi konvensional maupun perawatan pewarnaan gigi. Teknik mikroabrasi dapat merupakan perawatan tersendiri pada kasus ringan atau merupakan perawatan awal pada kasus berat dan kompleks.

Teknik mikroabrasi email merupakan teknik penanggulangan pewarnaan dengan menggunakan asam hidroklorit. Penggunaan teknik tersebut harus dilakukan oleh operator yang terampil dan dilakukan secara hati-hati, karena walaupun dalam konsentrasi rendah yaitu $11 \%$, menggunakan asam kuat berbahaya bagi jaringan lunak seperti kulit dan mukosa mulut. 
DAFTAR PUSTAKA

1. Akpata ES. Occurence and management of dental fluorosis. Int Dent J 2001; 51(5): 2325-33.

2. Cameron AC, Widmer RP. Handbook of pediatric dentistry. London: Mosby; 1997.

3. Dental fluorosis. [online] 2005 [cited 2005]. Available from URL http://www.google.com.

4. Chan DC, et al. The effect of microabrasion on restorative materials and tooth surface. Oper Dent 1996; 21(2): 63-8.

5. Croll TP. Enamel microabrasion: the technique. Quintessence Int 1989; 20(6).

6. Day T. Air abrasion. [online] 2005 [cited 2005]. Available from URL http:/www.dentalfind.com.

7. Air abrasion. [online] 2004 [cited 2004]. Available from URL http://www.planocosmeticdentist.com.

8. Fomon SJ, et al. Fluoride intake and prevalence of dental fluorosis: Trends in fluoride intake with special attention to infants. J Public Health dent 2000; 60 (3): 131-9.

9. Micro abrasion dentistry technology. [online] 2005 [cited 2005]. Available from URL http://www.

Kutschandrenyer. com.

10. Cutress TW, Suckling GW. Differential diagnosis of dental fluorosis. J Dent Res 1990; 69.

11. Dalzell DP, et al. Microabrasion: Effect of time, number of application, and pressure on enamel loss.Pediatr Dent 1995; 17(3): 207-11.

12. Air abrasion. [online] 2004 [cited 2004]. Available from URL http://www.agd.org/ consumer/topics/ airabrasion/main.html.

13. Air abrasion, microabrasion. [online] 2005 [cited 2005]. Available from URL http://www.pubmed. com. 